\title{
Evaluation of Chemically Coagulated Swine Manure Solids as Value-Added Products
}

\author{
Sammy Sadaka*, Karl Van Devender \\ Biological and Agricultural Engineering Department, Division of Agriculture, University of Arkansas, Little Rock, \\ AR, USA \\ Email: "ssadaka@uaex.edu
}

Received 2 September 2015; accepted 21 November 2015; published 24 November 2015

Copyright $@ 2015$ by authors and Scientific Research Publishing Inc.

This work is licensed under the Creative Commons Attribution International License (CC BY). http://creativecommons.org/licenses/by/4.0/

(c) (i) Open Access

\section{Abstract}

The objective of this research was to evaluate the chemically coagulated swine manure solids as biofuel and/or compost feedstock. Three coagulants, namely agricultural lime $\left[\mathrm{CaCO}_{3}\right]$, hydrated lime $\left[\mathrm{Ca}(\mathrm{OH})_{2}\right]$, and lime slurry $\left[\mathrm{Ca}(\mathrm{OH})_{2}\right]$, were added to fresh swine manure to coagulate manure solids. Four levels, i.e., $0.00(0.0 \mathrm{X}), 4.89(0.5 \mathrm{X}), 9.77(1.0 \mathrm{X})$, and $19.77(2.0 \mathrm{X}) \mathrm{gm} \mathrm{Ca}^{-1 i t e r}{ }^{-1}$, were tested, in triplicates. Increasing the coagulant concentration increased the total solids, ash content, and $\mathrm{pH}$ of solid manure samples, whereas it decreased their volatile solids, chemical oxygen demand, and heating value. At the coagulant level of $2.0 \mathrm{X}$ rate, heating values of samples coagulated by agricultural lime, hydrated lime, and lime slurry were $2.64,4.48$, and $4.54 \mathrm{MJ} \cdot \mathrm{kg}^{-1}$, respectively. The heating value of raw manure solids was as high as $13.49 \mathrm{MJ} \cdot \mathrm{kg}^{-1}$. Increasing the coagulant concentration increased the $\mathrm{O} / \mathrm{C}$ atomic ratio for all the studied coagulants. Accordingly, the high coagulant concentrations might reduce the acceptability of the feedstock as a biofuel that can be co-combusted with other feed stocks. The $\mathrm{C} / \mathrm{N}$ ratio and the $\mathrm{pH}$ values of the solid separated swine manure increased by increasing agricultural lime and hydrated lime concentrations. The former might increase satisfactoriness for composting these solids, whereas the latter might hinder their use in the composting process. The maximum coagulant concentrations that allowed pyrolyzing the final product, based on the net energy values, were $48.80(2.0 \mathrm{X}), 18.06(1.0 \mathrm{X})$, and $18.06(1.0 \mathrm{X})$ gm·liter ${ }^{-1}$ for agricultural lime, hydrated lime, and lime slurry, respectively. The maximum acceptable coagulant concentrations that allowed composting the final product, based on the pH values, were $48.80(2.0 \mathrm{X}), 0.00(0.0 \mathrm{X})$, and $9.03(0.5 \mathrm{X}) \mathrm{gm}^{\mathrm{g}} \cdot \mathrm{liter} \mathrm{r}^{-1}$ for the same three coagulants.

\section{Keywords}

Swine Manure, Solid Separation, Coagulation, Biofuel, Soil Amendment

\footnotetext{
${ }^{*}$ Corresponding author.
}

How to cite this paper: Sadaka, S. and Van Devender, K. (2015) Evaluation of Chemically Coagulated Swine Manure Solids as Value-Added Products. Journal of Sustainable Bioenergy Systems, 5, 136-150. 


\section{Introduction}

The total number of pigs in the United States had reached 65.9 million head, as recently published in the quarterly inventory report by the USDA [1]. Daily pig manure production was estimated to be $4.67 \mathrm{~kg} \cdot \mathrm{day}^{-1} \cdot \mathrm{animal}^{-1}$ [2]. Thus, the total amount of swine manure generated annually is more than 110 million metric tons. Land application of excessive volumes of swine manure creates environmental issues associated with nutrient loss to water bodies following manure application on fields [3]-[5].

Traditionally, land application of swine manure is considered the most common practical and economical utilization method [6]. Manure is a valuable source of nutrients, particularly nitrogen (N), phosphorus (P), and potassium (K), to plants when utilized in an environmentally sustainable manner [7] [8]. However, repeated manure land application on the same field to meet crop $\mathrm{N}$ requirements results in elevated $\mathrm{P}$ concentrations, which may lead to P loss to the environment through surface runoff or leaching [9] [10]. Consequently, regulatory agencies require strict application plans based on soil nutrient content $(\mathrm{N}, \mathrm{P})$ before issuing permits for manure land application [11].

Typically, the moisture content and total solids of fresh swine manure are about $90 \%$ w.b. and $10 \%$ w.b., respectively [2]. Manure high moisture content limits its long distance transportation. Liquid and solid fractions of swine manure could be separated and utilized via various techniques to convert them to value-added products and minimize their harmful effects. Solid-liquid separation has been employed in wastewater treatments for decades and provided a possible management technique for phosphorus and nitrogen [12]. The method involves the separation of solids from liquid manure using sedimentation (gravity settling), centrifugation, filtration (using belt presses, screw presses, and screens), or chemical amendment. All these techniques have been demonstrated to separate solids from manure slurries [13] [14]. Ideally, the separated solid fraction is rich in nutrients, particularly P, and can be hauled for application on P-deficient soils, whereas the liquid fraction can be used to irrigate fields without elevating the soil P [3] [15]. Employing solid-liquid separation as a tool for manure treatment not only potentially improves its handling properties but also generates manure solids that can be utilized for either compost production or energy generation [16].

Xiu et al. [17] report that chemical separation of manure solids is mostly accomplished using metal salts and organic flocculants that bring solubilized nutrients out of solution as fine particles, then form agglomerates of these salts, which can then quickly precipitate. Commonly used chemical amendments are metallic salts, especially those of iron (Fe), calcium (Ca), or aluminum (Al) and/or synthetic organic polymers, such as polyacrylamide (PAM) formulations [18]. Addition of coagulants, i.e., $\mathrm{FeCl}_{3}, \mathrm{Fe}_{2}\left(\mathrm{SO}_{4}\right)_{3}, \mathrm{Al}_{2}\left(\mathrm{SO}_{4}\right)$, and $\mathrm{CaCO}$, to manure results in coagulation of suspended particles by neutralizing the particles' negative surface charge and enhances $\mathrm{P}$ removal via coagulation of $\mathrm{P}$ by the cations constituting the coagulants [19]. Several studies have demonstrated that treatment of animal manure with coagulants and flocculants enhances solid-liquid separation [13] [20].

Reviewing the accessible literature reveals that there are no available data related to the energy contents and the thermal degradation behavior of the chemically coagulated swine manure solids. In addition, there are no data related to the maximum values of coagulants that will hinder the use of the final product as biofuel and/or compost feedstock. Consequently, swine producers, who practice manure-solid separation, should have interest in the determination of the optimum amount of coagulant additions and in the comparison between utilizing these solids as a biofuel or as a compost feedstock. Hence, the objective of this paper was to evaluate the chemically coagulated swine manure solids as a feedstock candidate for biofuel and/or compost.

\section{Materials and Methods}

\subsection{Swine Manure Solids Collection and Coagulant Addition}

Fresh swine manure was collected from a privately owned Arkansas farm. Three coagulants, namely agricultural lime $\left[\mathrm{CaCO}_{3}\right]$, hydrated lime powder $\left[\mathrm{Ca}(\mathrm{OH})_{2}\right]$, and lime slurry $\left[\mathrm{Ca}(\mathrm{OH})_{2}\right]$, were used to coagulate solids from fresh swine manure. Lime slurry was prepared by mixing the coagulant with water at the ratio of $0.3: 1.0 \mathrm{~kg} \cdot \mathrm{kg}^{-1}$, which is the mix ratio lime slurries starts behaving less as a suspension and more as a paste [21]. Mixing was accomplished using a battery powered drill and paint stirrer with less than 5 minutes of mixing needed. During the course of this study, coagulants were added to fresh swine manure in triplicates based at four levels of coagulant concentrations $\left(0.00,4.89,9.77\right.$, and $\left.19.77 \mathrm{gm} \mathrm{Ca} \cdot l i t e r^{-1}\right)$. These rates were set by mixing various volu- 
metric ratios of the lime slurry to sub samples of the liquid manure in clear containers. Visual determination of precipitate settling identified that $5 \%$ lime slurry is an acceptable treatment rate to balance chemical use and treatment effect. Based on this the 0.0X, 0.5X, 1.0X, 2.0X treatment rates for the lime slurry was set at $0 \%$, $2.5 \%, 5 \%$, and $10 \%$ on a volumetric rate. Hereinafter, they will be referred as $0.0 \mathrm{X}, 0.5 \mathrm{X}, 1.0 \mathrm{X}$, and $2.0 \mathrm{X}$, respectively. The equivalent mass of chemical addition; i.e., agricultural lime, hydrated lime, and lime slurry, are shown in Table 1. In this experiment, the specified amount of the chemical coagulant was mixed with 17 liters of fresh manure. Immediately the amended manure was poured into a second container lined with a 150-micron filter bag. The filter bag was lifted and suspended above the container to drain and naturally dry for 10 days. The coagulated, air-dried swine manure solid samples were collected and transported to the Rice Research and Extension Center lab, Stuttgart, Arkansas, for analyses.

\subsection{Physical, Chemical, and Thermochemical Analyses}

Physical, chemical, and thermochemical characteristics of the solid separated swine manure were determined in triplicates. Moisture content, volatile solids and ash content were determined according to the standard methods [22]-[24], respectively. Fixed carbon was obtained as the difference between dry weight and the sum of volatile solids and ash contents. The $\mathrm{pH}$ values of the manure samples were determined using an OMEGA Water Analyzer PHH-500 Series.

Chemical oxygen demand (COD) was employed in this study as an indirect measurement of soluble and insoluble organic matter in the manure samples. Samples were digested using a HACH DRB200 Digester, Germany. Following, a HACH DR7200 Spectrophotometer, Germany, was used to measure the COD. The ultimate and ash analyses were performed in a specialized diagnostic laboratory (Huffman Laboratories Inc., Golden, Colorado, USA). Samples' carbon, hydrogen, and nitrogen contents were determined according to standard ASTM D5373-14 [25], while sulfur was determined using standard ASTM D4239-14e1 [26]. The elemental analyses of the ash oxides were quantified according to standard ASTM 6349. Higher heating values were determined using an oxygen bomb calorimeter (Parr instruments, Model1241, Moline, Illinois, USA) according to ASTM Standard D5865-12 [27]. The calorimeter was used to burn a small mass of well dried feedstock samples in the presence of oxygen inside a sealed container.

\subsection{Thermal Degradation}

The pyrolysis of raw manure, agricultural lime, hydrated lime, and chemically coagulated samples, was investigated using a thermogravimetric analyzer (Model TGA 4000, Perkin Elmer, Inc., Waltham, Massachusetts). To ensure that the decomposition was controlled by kinetics rather than diffusion, the particle size and the sample size were kept small. The dry samples were first milled and sieved to generate a subsample with a particle size less than $0.2 \mathrm{~mm}$. The sample weight was maintained at $5 \mathrm{mg}( \pm 0.1 \mathrm{mg})$ in all the TGA tests. The analyzer was used to determine the relationship between the temperature and weight loss for the different samples under oxy-

Table 1. Chemical coagulants utilized in manure solids separation.

\begin{tabular}{|c|c|c|c|}
\hline Treatment & Level & $\begin{array}{l}\text { Chemical }{ }^{1} \text { mass added per liter of liquid manure } \\
\left(\mathrm{gm} \cdot \mathrm{l}^{-1}\right)\end{array}$ & $\begin{array}{l}\text { Calcium mass added per liter of liquid manure } \\
\qquad\left(\mathrm{gm} \cdot \mathrm{l}^{-1}\right)\end{array}$ \\
\hline Manure & Raw & - & - \\
\hline \multirow{3}{*}{$\begin{array}{c}\text { Agricultural } \\
\text { Lime } \\
\mathrm{CaCO}_{3}\end{array}$} & $0.5 \mathrm{X}$ & 12.20 & 4.89 \\
\hline & $1.0 \mathrm{X}$ & 24.40 & 9.77 \\
\hline & $2.0 \mathrm{X}$ & 48.80 & 19.55 \\
\hline \multirow{3}{*}{$\begin{array}{l}\text { Hydrated } \\
\text { Lime } \\
\mathrm{Ca}(\mathrm{OH})_{2}\end{array}$} & $0.5 \mathrm{X}$ & 9.03 & 4.89 \\
\hline & $1.0 \mathrm{X}$ & 18.06 & 9.77 \\
\hline & $2.0 \mathrm{X}$ & 36.13 & 19.55 \\
\hline \multirow{3}{*}{$\begin{array}{c}\text { Lime } \\
\text { Slurry } \\
\mathrm{Ca}(\mathrm{OH})_{2}\end{array}$} & $0.5 \mathrm{X}$ & 9.03 & 4.89 \\
\hline & $1.0 \mathrm{X}$ & 18.06 & 9.77 \\
\hline & $2.0 \mathrm{X}$ & 36.13 & 19.55 \\
\hline
\end{tabular}

${ }^{1}$ Mass of $\mathrm{CaCO}_{3}$ and $\mathrm{Ca}(\mathrm{OH})_{2}$ only added assuming chemicals are $100 \%$ pure. 
gen-free conditions. Nitrogen was used as the purge gas $\left(50 \mathrm{~mL} \cdot \mathrm{min}^{-1}\right)$, at a heating rate of $5^{\circ} \mathrm{C} \cdot \mathrm{min}^{-1}$. Each sample was placed in a clean, inert alumina $\left(\mathrm{Al}_{2} \mathrm{O}_{3}\right)$ crucible. A blank test was conducted with an empty crucible under the regular test conditions to quantify the buoyancy of the crucible. The experimental data was then corrected by subtracting the blank test results.

\subsection{Statistical Analysis}

The results were analyzed using JMP ${ }^{\circledR}$ Pro software (version 11.0.0, SAS Institute Inc., Cary, North Carolina). Two-way ANOVA was used to analyze the impact of coagulant type and concentration on the characteristics of the feedstock.

\section{Results and Discussion}

Evaluation of the coagulated swine manure solids, as biofuel and/or composting feedstock, requires comprehensive analyses that determine the acceptable levels of the concentrations of each coagulant. The following section details the results of the lab analyses performed on the swine manure solids.

\subsection{Physical, Chemical, and Thermochemical Characteristics of Coagulated Swine Manure Solids}

The average total solids of raw manure were found to be $32.1 \% \pm 4.9 \%$, as shown in Table 2 . The volatile solids, ash, and fixed carbon content were $54.9 \% \pm 1.8 \%, 30.5 \% \pm 1.6 \%$, and $14.7 \% \pm 0.4 \%$, respectively. Increasing the concentration of the agricultural lime, hydrated lime, and lime slurry increased the total solids and ash contents in varying degrees. The highest total solids value of $68.0 \% \pm 2.1 \%$ was achieved with the agricultural lime $2.0 \mathrm{X}$, whereas the lowest total solids value of $33.1 \% \pm 4.2 \%$ was observed with lime slurry of $0.5 \mathrm{X}$. The increase in the total solids could be attributed to the rise in the chemical coagulant concentration in the manure samples. As shown earlier in Table 1, the mass of agricultural lime addition to fresh manure samples was higher than that added to either hydrated lime or lime slurry. These results are slightly lower than the results reported in the literature. Riano and Garcia-Gonzalez [3] found that the total solids produced from swine manure solids separated by a screw press and a coagulation-flocculation unit reached $73.3 \%$ and $85.4 \%$, respectively. This could be attributed to the nature of the diet or the collection technique. Statistical analysis of the total solids values showed a significant effect of coagulant concentrations as compared with raw manure $(\mathrm{P}<0.05)$. There was no significant difference between the values of total solids of both hydrated lime and lime slurry. Comparison of means showed the total solids in high coagulant concentration to be significantly greater than total solids of mixtures under low $(0.5 \mathrm{X})$ coagulant concentration $(\mathrm{P}<0.05)$. Ash content, in the present study, also increased in the solid separated swine manure samples due to the rise in the inorganic component represented in coagulants. Ash concentration rose by $12.6 \%$ and $24.1 \%$ as the coagulant concentration increased from $0.5 \mathrm{X}$ to $2.0 \mathrm{X}$ for the agricultural lime and hydrated lime, respectively. Increasing lime slurry concentration did not show a

Table 2. Proximate analysis and bulk density of raw swine manure and amendment samples.

\begin{tabular}{|c|c|c|c|c|c|}
\hline Treatment & Level & Total solids ${ }^{1}(\%)$ & Volatile solids (\%) & Ash (\%) & Fixed carbon (\%) \\
\hline \multirow[t]{2}{*}{ Manure } & Raw & $32.1^{\mathrm{a}} \pm 4.9$ & $54.9^{\mathrm{a}} \pm 1.8$ & $30.5^{\mathrm{a}} \pm 1.6$ & $14.7^{\mathrm{a}} \pm 0.4$ \\
\hline & $0.5 \mathrm{X}$ & $56.7^{\mathrm{e}} \pm 3.4$ & $34.6^{\mathrm{b}} \pm 4.1$ & $46.8^{\mathrm{b}} \pm 1.3$ & $18.6^{\mathrm{b}} \pm 3.2$ \\
\hline \multirow[t]{3}{*}{ Agricultural Lime } & $1.0 \mathrm{X}$ & $66.2^{\mathrm{f}} \pm 5.6$ & $24.5^{\mathrm{d}} \pm 2.6$ & $50.7^{\text {cde }} \pm 1.9$ & $24.8^{\mathrm{c}} \pm 0.9$ \\
\hline & $2.0 \mathrm{X}$ & $68.0^{\mathrm{f}} \pm 2.1$ & $18.0^{\mathrm{f}} \pm 1.4$ & $52.7^{\mathrm{e}} \pm 0.7$ & $29.4^{\mathrm{d}} \pm 0.7$ \\
\hline & $0.5 X$ & $35.7^{\mathrm{bc}} \pm 0.9$ & $33.8^{\mathrm{b}} \pm 3.3$ & $48.6^{\mathrm{bcd}} \pm 4.1$ & $17.6^{\mathrm{ab}} \pm 0.8$ \\
\hline \multirow[t]{3}{*}{ Hydrated Lime } & $1.0 \mathrm{X}$ & $39.3^{\mathrm{cd}} \pm 3.5$ & $23.9^{\mathrm{de}} \pm 1.2$ & $57.3^{f} \pm 3.0$ & $18.7^{\mathrm{b}} \pm 2.0$ \\
\hline & $2.0 \mathrm{X}$ & $40.8^{\mathrm{d}} \pm 1.3$ & $21.1^{\mathrm{ef}} \pm 1.6$ & $60.3^{f} \pm 2.8$ & $18.6^{\mathrm{b}} \pm 4.3$ \\
\hline & $0.5 \mathrm{X}$ & $33.1^{\mathrm{ab}} \pm 4.2$ & $35.5^{\mathrm{b}} \pm 0.9$ & $48.1^{\mathrm{bc}} \pm 0.5$ & $16.5^{\mathrm{b}} \pm 0.4$ \\
\hline \multirow[t]{2}{*}{ Lime Slurry } & $1.0 \mathrm{X}$ & $35.6^{\mathrm{bc}} \pm 1.5$ & $30.3^{\mathrm{c}} \pm 0.3$ & $51.6^{\mathrm{de}} \pm 1.1$ & $18.2^{\mathrm{b}} \pm 1.3$ \\
\hline & $2.0 \mathrm{X}$ & $39.1^{\mathrm{cd}} \pm 0.2$ & $29.9^{c} \pm 0.3$ & $47.8^{\mathrm{bc}} \pm 1.2$ & $22.3^{c} \pm 3.0$ \\
\hline
\end{tabular}

${ }^{1}$ Averages within a column followed by different letter are significantly different at $\mathrm{P} \leq 0.05$ level and $\mathrm{n}=3$. 
clear trend. These high values of the ash contents might hinder the suitability of these feedstocks being utilized in thermochemical conversion processes. A significant effect $(\mathrm{P}<0.05)$ was observed between samples having various coagulant concentrations. Low concentration of hydrated lime or lime slurry addition $(0.5 \mathrm{X})$ did not show the significant difference as compared with manure samples. However, the addition of agricultural lime showed a significant difference from hydrated lime and lime slurry $(\mathrm{P}<0.05)$. A wide range of the ash content was reported previously in the literature. Jørgensen and Jensen [28] reported that the ash content ranged between 8.0 and $37.4 \%$. Wnetrzak et al. [29] found that the ash content reached $22.2 \%$ during the testing of swine manure solid separation using chemical pretreatment and a mechanical separation system.

Conversely, for the present study, volatile solids concentrations in the manure samples decreased as the coagulant concentration increased, as shown in Table 2. Volatile content is the energy-rich fraction that fuels the heating necessary for both thermochemical and biological conversion processes. Increasing the coagulant concentration from $0.5 \mathrm{X}$ to $2.0 \mathrm{X}$ decreased the volatile solids from $34.6 \% \pm 4.1 \%$ to $18.0 \% \pm 1.4 \%$, from $33.8 \% \pm$ $3.3 \%$ to $21.1 \% \pm 1.6 \%$, and from $35.5 \% \pm 0.9 \%$ to $29.9 \% \pm 0.3 \%$ for agricultural lime, hydrated lime, and lime slurry, respectively. This is a result of the increase of coagulant concentration. Higher values of volatile solids results were reported by Xiu et al. [17]. They found the volatile solids to be about $65.5 \%$ when they separated solids using centrifugal force.

Table 3 summarizes the effects of coagulant type and concentration on the $\mathrm{pH}$ and chemical oxygen demand of solid coagulated swine manure. Raw swine manure $\mathrm{pH}$ value was $7.1 \pm 0.2$ (slightly greater than the neutral value of 7.0). For the amended samples, the lowest observed $\mathrm{pH}$ values were found with the addition of agricultural lime as compared with the other two chemical coagulants, i.e., hydrated lime and lime slurry. Hydrated lime addition increased the $\mathrm{pH}$ values of the samples to 12.3, 12.5, and 12.6 under the coagulant concentrations of $0.5 \mathrm{X}, 1.0 \mathrm{X}$, and 2.0X, respectively. Marchetti et al. [30] also reported that adding a chemical coagulant to separate swine manure solids increased the $\mathrm{pH}$ values towards the alkaline levels. They mentioned that the $\mathrm{pH}$ value of raw manure before and after the chemical treatment were8.00 and 9.65, respectively. Significant differences $(\mathrm{P}<0.05)$ were observed between all the tested coagulant concentration levels as well as between the coagulant types for $\mathrm{pH}$ values.

Chemical oxygen demand of manure samples (Table 3) was used to measure the oxygen equivalent of the solid separated swine manure subjected to oxidation by a strong chemical oxidant. Adding $0.5 \mathrm{X}$ hydrated lime and lime slurry to manure increased the chemical oxygen demand (COD) from $1777.5 \pm 406.3 \mathrm{mg} \cdot \mathrm{kg}^{-1}$ to $2916.7 \pm 376.3 \mathrm{mg} \cdot \mathrm{kg}^{-1}$ and $2777.3 \pm 508.4 \mathrm{mg} \cdot \mathrm{kg}^{-1}$, respectively. Conversely, adding $0.5 \mathrm{X}$ agricultural lime concentration to fresh manure decreased the COD significantly. With further increase of the agricultural lime concentration, the COD values continued to decrease significantly $(\mathrm{P}<0.05)$. Vanotti et al. [31] reported a significant decrease (83\%) of the COD concentration of manure treated with a polymer and filtered through sand.

The highest heating value of $13.49 \pm 0.42 \mathrm{MJ} \cdot \mathrm{kg}^{-1}$ was observed with the raw manure sample (Table 3). Tsai et al. [32] reported the heating value of manure solids to be as high as $19.4 \mathrm{MJ} \cdot \mathrm{kg}^{-1}$. Additionally, Park et al. [33] reported higher heating values of $22.3 \mathrm{MJ} \cdot \mathrm{kg}^{-1}$. In contrast, Wnetrzak et al. [29] reported the higher heating value

Table 3. Chemical and the thermochemical characteristics of raw swine manure and amendment samples.

\begin{tabular}{|c|c|c|c|c|}
\hline Treatment & Level & $\mathbf{p H}^{1}(-)$ & Chemical oxygen demand $\left(\mathrm{mg} \cdot \mathrm{g}^{-1}\right)$ & Higher heating value $\left(\mathrm{MJ} \cdot \mathrm{kg}^{-1}\right)$ \\
\hline \multirow[t]{2}{*}{ Manure } & Raw & $7.1^{\mathrm{a}} \pm 0.2$ & $1777.5^{d} \pm 406.3$ & $13.49^{f} \pm 0.42$ \\
\hline & $0.5 \mathrm{X}$ & $7.1^{\mathrm{b}} \pm 0.0$ & $1003.5^{\mathrm{abc}} \pm 129.0$ & $5.79^{\mathrm{cd}} \pm 0.68$ \\
\hline \multirow[t]{3}{*}{ Agricultural lime } & $1.0 \mathrm{X}$ & $7.4^{\mathrm{c}} \pm 0.2$ & $950.0^{\mathrm{ab}} \pm 140.0$ & $4.51^{\mathrm{b}} \pm 0.46$ \\
\hline & $2.0 \mathrm{X}$ & $7.5^{\mathrm{c}} \pm 0.0$ & $640.0^{\mathrm{a}} \pm 17.3$ & $2.64^{\mathrm{ba}} \pm 0.68$ \\
\hline & $0.5 \mathrm{X}$ & $12.3^{\mathrm{e}} \pm 0.1$ & $2916.7^{\mathrm{f}} \pm 376.3$ & $7.39^{\mathrm{e}} \pm 0.38$ \\
\hline \multirow[t]{3}{*}{ Hydrated lime } & $1.0 \mathrm{X}$ & $12.5^{\mathrm{fg}} \pm 0.0$ & $1886.7^{\mathrm{d}} \pm 118.5$ & $5.81^{\mathrm{cd}} \pm 0.33$ \\
\hline & $2.0 \mathrm{X}$ & $12.6^{\mathrm{g}} \pm 0.0$ & $1316.7^{\mathrm{bc}} \pm 40.4$ & $4.48^{\mathrm{C}} \pm 0.70$ \\
\hline & $0.5 \mathrm{X}$ & $8.7^{\mathrm{d}} \pm 0.1$ & $2773.3^{\mathrm{ef}} \pm 508.4$ & $7.60^{g} \pm 0.09$ \\
\hline \multirow[t]{2}{*}{ Lime slurry } & $1.0 \mathrm{X}$ & $12.4^{\mathrm{ef}} \pm 0.0$ & $2343.3^{\mathrm{e}} \pm 134.3$ & $6.38^{\mathrm{f}} \pm 0.07$ \\
\hline & $2.0 \mathrm{X}$ & $12.5^{\mathrm{g}} \pm 0.0$ & $1440.0^{\text {cd }} \pm 52.9$ & $4.54^{\mathrm{a}} \pm 0.04$ \\
\hline
\end{tabular}

\footnotetext{
${ }^{1}$ Averages within a column followed by a different letter are significantly different at $\mathrm{P} \leq 0.05$ level and $\mathrm{n}=3$.
} 
of $14.3 \mathrm{MJ} \cdot \mathrm{kg}^{-1}$ for chemically pretreated swine manure solids followed by mechanical separation. The lower heating value in the present study might be due to the collection technique of the manure samples. Increasing the coagulant concentration decreased the samples' heating value. The heating value dropped by $80.4 \%, 66 . x \%$, and $66.3 \%$ corresponding to $2.0 \mathrm{X}$ concentration of agricultural lime, hydrated lime, and lime slurry, respectively. Table 3 also shows that there was a significant effect of adding agricultural lime on the heating value $(\mathrm{P}<0.05)$. This decline is attributed to the increase of the inorganic fraction in the manure sample by increasing the coagulant concentration.

The results of the ultimate analysis conducted on the manure samples amended by the three studied coagulants, i.e., agricultural lime, hydrated lime, and lime slurry, and the four levels of coagulant concentrations are shown in Table 4. Ultimate analysis of coagulated manure samples provides the weight fraction of its elemental constituents. The weight percentage of these elements was determined in dry basis. The primary elements constituting manure samples are carbon, hydrogen, oxygen, and nitrogen. These major elements are important in assessing the energy value and the suitability of the coagulated samples as biofuel. Low concentrations of sulfur were also found. Carbon concentration varied from $34.46 \%$ in raw manure to $17.34 \%$ in agricultural lime (2.0X), $12.99 \%$ in hydrated lime (2.0X), and $14.68 \%$ in lime slurry (2.0X) treatments. Similarly, hydrogen and nitrogen concentrations decreased by increasing the coagulant concentrations. Similar results of carbon and hydrogen concentrations of solid separated manure were reported by Wnetrzak et al. [29]. Sulfur also changed negatively by increasing the coagulant concentration. Adding 2.0X of agricultural lime, hydrated lime, and lime slurry to manure samples decreased the sulfur concentration to $0.20 \%, 0.22 \%$, and $0.25 \%$, respectively. Empirical chemical formulae were determined for the raw and amended manure samples based on their chemical compositions. The molecular weights of the raw manure reached 22.02. Adding 2.0X of agricultural lime, hydrated lime, and lime slurry increased the molecular weight to $32.25,35.66$, and 41.72 , respectively.

The composition of the ash of the separated swine manure solids is presented in Table 5 in the form of percent oxides of the mineral elements. The primary mineral elemental oxides found in the solid manure ash samples were phosphorus, calcium, potassium, and magnesium oxides. These elements provide information on the products during the thermochemical conversion process concerning environmental pollution problems. Phosphorus, calcium, magnesium, and potassium oxides of raw manure ashes reached $37.40 \%, 21.22 \%, 13.07 \%$, and $4.65 \%$, respectively. Increasing the coagulant concentration decreased the concentration of $\mathrm{P}_{2} \mathrm{O}_{5}, \mathrm{~K}_{2} \mathrm{O}$, and $\mathrm{MgO}$ and increased the concentration of $\mathrm{CaO}$. The pronounced rise in the calcium oxide in the present study is due to the addition of a calcium-based amendment to the liquid manure. Small amounts of $\mathrm{Na}_{2} \mathrm{O}, \mathrm{ZnO}, \mathrm{Fe}_{2} \mathrm{O}_{3}, \mathrm{CuO}$, and $\mathrm{MnO}$ were detected in the solid coagulated manure samples.

Figure 1(a) shows the pyrolysis weightloss as a function of temperature for the raw separated manure, agricultural lime, and hydrated lime. The weight-loss derivative curves (DTG), illustrated in Figure 1(b), elucidate the various decomposition stages for these feedstocks. In the raw manure, the weight loss proceeded in two consecutive stages: drying and devolatilization. The first stage, i.e., drying, took place between $60^{\circ} \mathrm{C}$ and $105^{\circ} \mathrm{C}$ as the first weight-loss peak indicates. The volatile matter loss, the second phase, i.e., devolatilization, took

Table 4. Ultimate analysis, empirical formula and molecular weight of raw swine manure solids and amendment samples.

\begin{tabular}{ccccccccc}
\hline Treatment & Level & $\mathbf{C}(\%)$ & $\mathbf{H}(\%)$ & $\mathbf{N}(\%)$ & $\mathbf{O}(\%)$ & $\mathbf{S}(\%)$ & Empirical formula (-) & Molecular weight $\left(\mathbf{g} \cdot \mathbf{m o l}^{-\mathbf{1}}\right)$ \\
\hline Manure & $\mathrm{Raw}$ & 34.46 & 4.60 & 3.86 & 23.35 & 0.83 & $\mathrm{CH}_{1.602} \mathrm{O}_{0.508} \mathrm{~N}_{0.960} \mathrm{~S}_{0.009}$ & 22.02 \\
& $0.5 \mathrm{X}$ & 22.38 & 2.21 & 1.44 & 26.35 & 0.39 & $\mathrm{CH}_{1.185} \mathrm{O}_{0.883} \mathrm{~N}_{0.055} \mathrm{~S}_{0.007}$ & 27.52 \\
$\begin{array}{c}\text { Agricultural } \\
\text { lime }\end{array}$ & $1.0 \mathrm{X}$ & 19.11 & 1.60 & 0.97 & 27.22 & 0.25 & $\mathrm{CH}_{1.105} \mathrm{O}_{1.068} \mathrm{~N}_{0.044} \mathrm{~S}_{0.005}$ & 30.25 \\
& $2.0 \mathrm{X}$ & 17.34 & 1.28 & 0.78 & 27.78 & 0.20 & $\mathrm{CH}_{0.886} \mathrm{O}_{1.202} \mathrm{~N}_{0.390} \mathrm{~S}_{0.004}$ & 32.25 \\
& $0.5 \mathrm{X}$ & 23.23 & 2.83 & 1.28 & 23.64 & 0.42 & $\mathrm{CH}_{1.462} \mathrm{O}_{0.763} \mathrm{~N}_{0.047} \mathrm{~S}_{0.007}$ & 25.89 \\
Hydrated lime & $1.0 \mathrm{X}$ & 15.98 & 2.68 & 0.84 & 23.19 & 0.30 & $\mathrm{CH}_{2.013} \mathrm{O}_{1.088} \mathrm{~N}_{0.045} \mathrm{~S}_{0.007}$ & 31.65 \\
& $2.0 \mathrm{X}$ & 12.99 & 2.51 & 0.67 & 22.88 & 0.22 & $\mathrm{CH}_{2.319} \mathrm{O}_{1.321} \mathrm{~N}_{0.044} \mathrm{~S}_{0.006}$ & 35.66 \\
Lime & $0.5 \mathrm{X}$ & 23.79 & 2.73 & 1.32 & 23.48 & 0.42 & $\mathrm{CH}_{1.377} \mathrm{O}_{0.740} \mathrm{~N}_{0.048} \mathrm{~S}_{0.007}$ & 25.43 \\
& $1.0 \mathrm{X}$ & 20.62 & 2.53 & 1.22 & 23.80 & 0.37 & $\mathrm{CH}_{1.147} \mathrm{O}_{0.866} \mathrm{~N}_{0.051} \mathrm{~S}_{0.007}$ & 27.54 \\
\hline
\end{tabular}


Table 5. Ash metal oxides for raw swine manure solids and amendment samples.

\begin{tabular}{ccccccccccc}
\hline Treatment & Level & $\mathbf{P}_{\mathbf{2}} \mathbf{O}_{\mathbf{5}}(\%)$ & $\mathbf{K}_{\mathbf{2}} \mathbf{O}(\%)$ & $\mathbf{C a O}(\%)$ & $\mathbf{M g O}(\%)$ & $\mathbf{N a}_{\mathbf{2}} \mathbf{O}(\%)$ & $\mathbf{Z n O}(\%)$ & $\mathbf{F e}_{2} \mathbf{O}_{\mathbf{3}}(\%)$ & $\mathbf{C u O}(\%)$ & $\mathbf{M n O}(\%)$ \\
\hline Manure & $\mathrm{Raw}$ & 37.40 & 4.65 & 21.22 & 13.07 & 1.22 & $\mathrm{NM}$ & 2.29 & $\mathrm{NM}^{1}$ & 0.32 \\
& $0.5 \mathrm{X}$ & 12.35 & 1.65 & 66.34 & 4.61 & 0.43 & 0.42 & 0.82 & 0.02 & 0.15 \\
Agricultural & $1.0 \mathrm{X}$ & 8.27 & 1.13 & 72.47 & 3.10 & 0.30 & 0.16 & 0.61 & 0.01 & 0.12 \\
$\quad$ Lime & $2.0 \mathrm{X}$ & 6.42 & 0.88 & 75.51 & 2.55 & 0.23 & 0.12 & 0.52 & 0.01 & 0.10 \\
& $0.5 \mathrm{X}$ & 16.23 & 2.30 & 62.26 & 5.48 & 0.64 & 0.25 & 0.89 & 0.02 & 0.16 \\
Hydrated Lime & $1.0 \mathrm{X}$ & 9.23 & 1.33 & 74.54 & 3.31 & 0.38 & 0.13 & 0.54 & 0.01 & 0.12 \\
& $2.0 \mathrm{X}$ & 6.39 & 0.98 & 82.21 & 2.46 & 0.27 & 0.10 & 0.40 & 0.01 & 0.10 \\
Lime & $0.5 \mathrm{X}$ & 17.52 & 2.42 & 61.30 & 5.64 & 0.72 & 0.28 & 0.90 & 0.03 & 0.16 \\
Slurry & $1.0 \mathrm{X}$ & 11.70 & 1.61 & 69.68 & 3.98 & 0.45 & 0.20 & 0.70 & 0.02 & 0.14 \\
& $2.0 \mathrm{X}$ & 8.48 & 1.21 & 97.13 & 3.18 & 0.34 & 0.15 & 0.55 & 0.01 & 0.13 \\
\hline
\end{tabular}

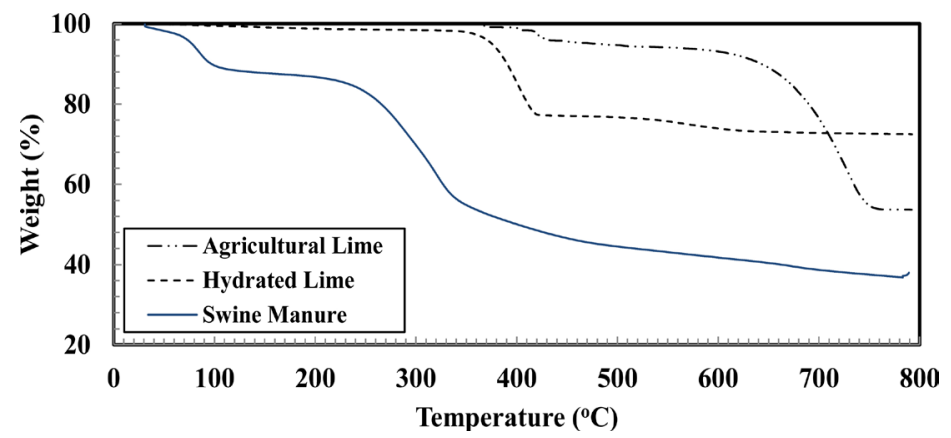

(a)

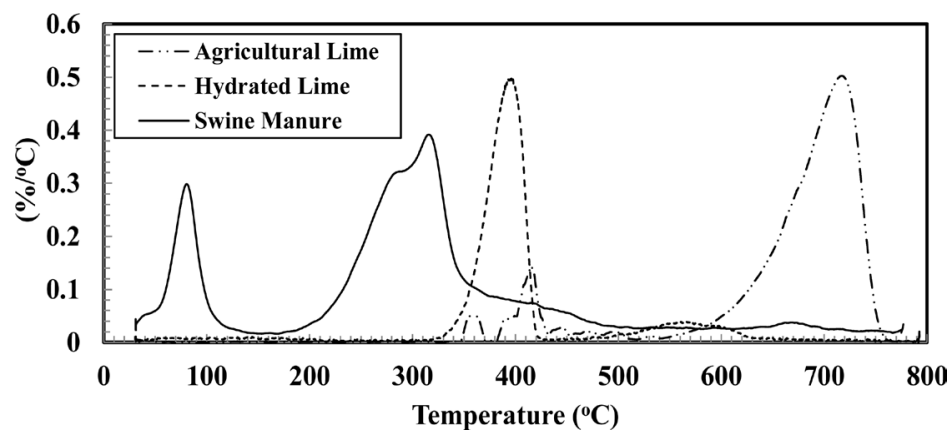

(b)

Figure 1. Agricultural lime, hydrated lime and swine manure (a) weight loss, (b) weight loss derivative.

place between $220^{\circ} \mathrm{C}$ and $350^{\circ} \mathrm{C}$. Devolatilization of raw manure reached its peak value of $0.392 \%{ }^{\circ} \mathrm{C}^{-1}$ at the temperature level of $315.9^{\circ} \mathrm{C}$ (Table 6). Park et al. [33] used a TGA to determine the thermal decomposition of swine manure under nitrogen environment. They reported that the mass change in the first stage reached $1.2 \% \cdot{ }^{\circ} \mathrm{C}^{-1}$. Additionally, they reported $40.9 \%$ and $37.5 \%$ mass changes between $200^{\circ} \mathrm{C}$ to $400^{\circ} \mathrm{C}$ and $400^{\circ} \mathrm{C}$ to $600^{\circ} \mathrm{C}$, respectively. Fresh agricultural lime showed a small peak as compared with raw manure and hydrated lime. However, hydrated lime showed a clear decomposition stage between $340^{\circ} \mathrm{C}$ and $430^{\circ} \mathrm{C}$. At the temperature levels of $415.4^{\circ} \mathrm{C}$ and $395.2^{\circ} \mathrm{C}$, the devolatilization peak reached $0.144^{\circ} \mathrm{C} \cdot \mathrm{min}^{-1}$ and $0.500^{\circ} \mathrm{C} \cdot \mathrm{min}^{-1}$ for agricultural lime and hydrated lime, respectively. Accordingly, the agricultural lime could be considered a thermally stable feedstock. Its major decomposition stage was delayed to higher than $600^{\circ} \mathrm{C}$ and ended at $750^{\circ} \mathrm{C}$. Zhang et al. [34] also reported two distinctive stages of thermal decomposition of calcium compounds. They reported that the first phase took place between $400^{\circ} \mathrm{C}$ and $600^{\circ} \mathrm{C}$ and the second phase took place above $700^{\circ} \mathrm{C}$.

Amended manure samples using agricultural lime, hydrated lime, and lime slurry showed various levels of decomposition stages. Figures 2-4 show the weight loss and the weight-loss derivative curves of the manure 
samples amended by the three coagulants, i.e., agricultural lime, hydrated lime, and lime slurry. Two weightloss peaks were detected during the pyrolysis of the manure samples amended with agricultural lime. The temperatures, corresponding to the decomposition peaks in the first stage as compared to those for raw manure, are listed in Table 6.

Manure samples amended with hydrated lime and lime slurry showed three decomposition stages: two small peaks $\left(220^{\circ} \mathrm{C}-420^{\circ} \mathrm{C}\right)$ and a larger one that took place under the temperature range of $600^{\circ} \mathrm{C}$ to $715^{\circ} \mathrm{C}$. These observations indicate that under extremely high temperature levels $\left(650^{\circ} \mathrm{C}-750^{\circ} \mathrm{C}\right)$ full decomposition of the coagulant is achievable. It is worth noting that, in the current study, the decomposition peaks did not follow a clear trend by increasing the coagulant concentration. This observation could be attributed to the fact that under pyrolysis conditions or any thermal treatment, the original feedstock matrix is transformed into a new structure biochar that might have its thermal properties.

Table 6. Pyrolysis characteristics for raw manure, coagulants, and coagulated solids.

\begin{tabular}{ccccc}
\hline Treatment & Level & $\boldsymbol{T}_{\mathbf{p} 1}\left({ }^{\circ} \mathbf{C}\right)$ & $\mathbf{( d W / d t})_{\mathbf{p} 1}\left(\mathbf{m g} \cdot \mathbf{s}^{-1}\right)$ & Energy required for pyrolysis $\left(\mathbf{M J} \cdot \mathbf{k g}^{-\mathbf{1}}\right)$ \\
\hline Manure & Raw & 315.9 & 0.392 & 6.37 \\
Agricultural lime & Raw & 415.4 & 0.144 & - \\
Hydrated lime & Raw & 395.2 & 0.500 & - \\
Agricultural & $0.5 \mathrm{X}$ & 316.0 & 0.222 & 3.16 \\
lime & $1.0 \mathrm{X}$ & 311.8 & 0.277 & 2.56 \\
& $2.0 \mathrm{X}$ & 299.9 & 0.186 & 2.47 \\
Hydrated & $0.5 \mathrm{X}$ & 294.4 & 0.144 & 5.63 \\
lime & $1.0 \mathrm{X}$ & 391.6 & 0.141 & 5.02 \\
& $2.0 \mathrm{X}$ & 396.7 & 0.158 & 4.80 \\
Lime & $0.5 \mathrm{X}$ & 297.9 & 0.195 & 6.15 \\
slurry & $1.0 \mathrm{X}$ & 288.3 & 0.114 & 5.65 \\
& $2.0 \mathrm{X}$ & 293.6 & 0.0 .06 & 5.05 \\
\hline
\end{tabular}

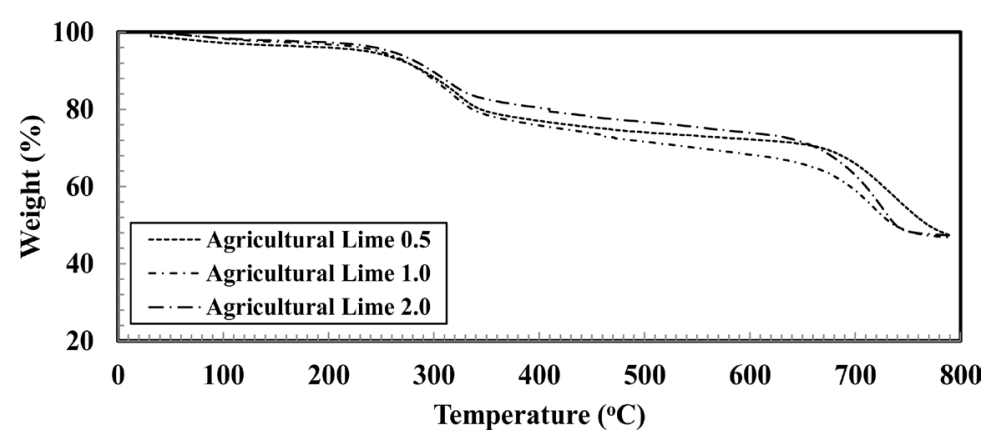

(a)

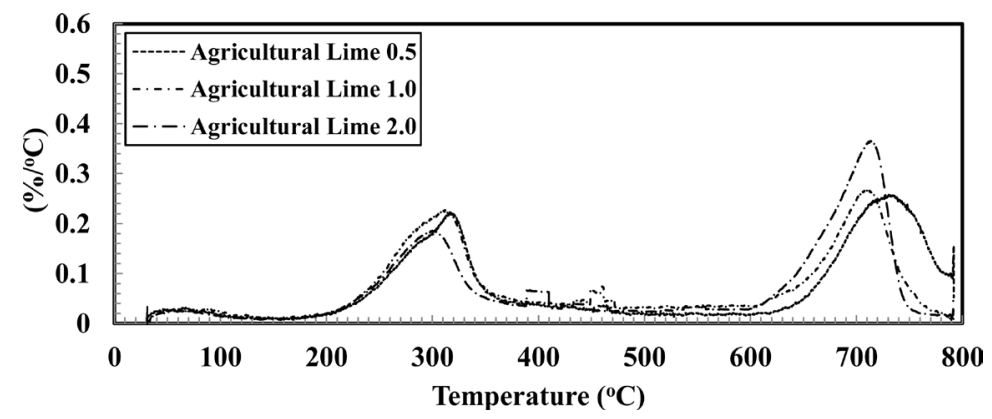

(b)

Figure 2. Samples amendment with agricultural lime (a) weight loss, (b) weight loss derivative. 


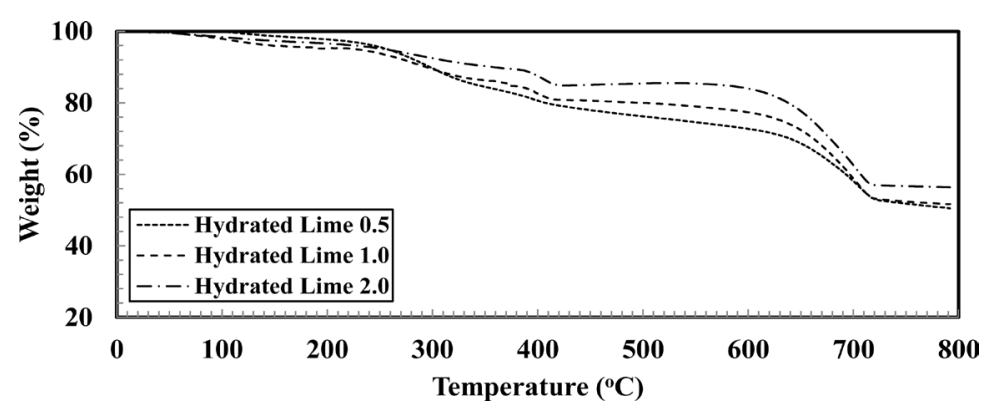

(a)

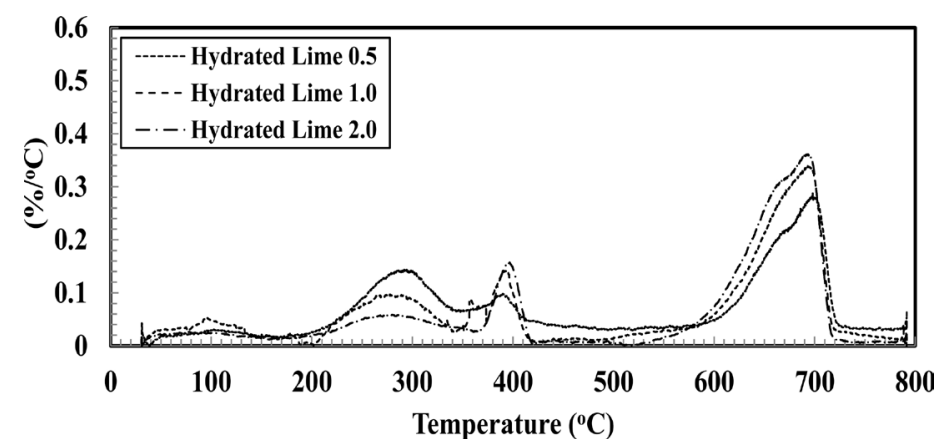

(b)

Figure 3. Samples amendment with hydrated lime (a) weight loss, (b) weight loss derivative.

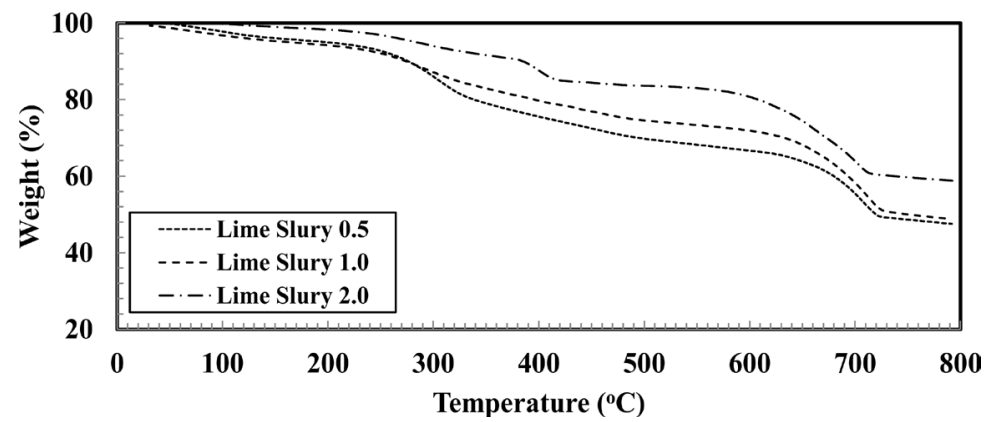

(a)

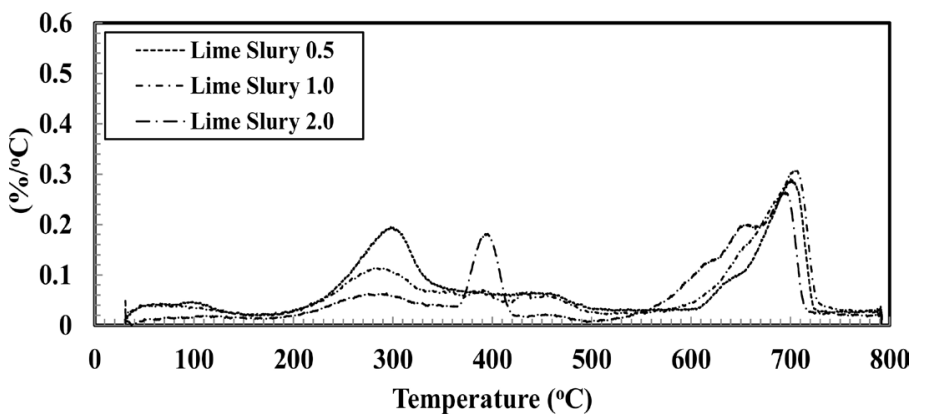

(b)

Figure 4. Samples amendment with lime slurry (a) weight loss, (b) weight loss derivative.

\subsection{Assessment of Coagulated Swine Manure Solids as a Biofuel Feedstock}

In addition to the energy content of the solid separated swine manure and its thermal degradation, which were mentioned earlier, it was essential to compare the carbon, hydrogen and oxygen relationships of these feed stocks. Figure 5 illustrates the effects of the coagulant addition on the O/C versus $\mathrm{H} / \mathrm{C}$ atomic ratios along with 


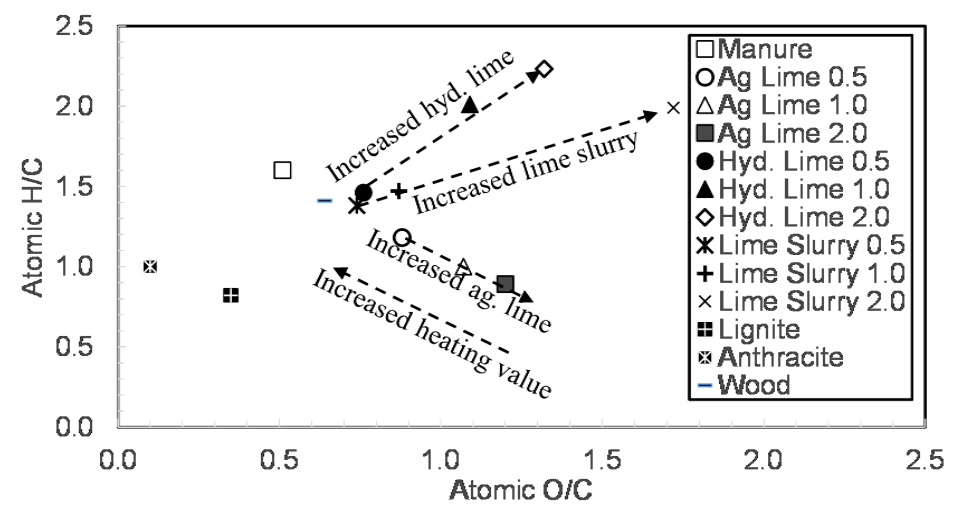

Figure 5. Van Krevelen diagram for raw swine manure and amendment samples as compared with coal and cottonwood.

two types of coal and cottonwood for comparison. A similar diagram was developed by Van Krevelen [35] to study the quality of coal. The graph shows that decreasing the $\mathrm{O} / \mathrm{C}$ and increasing the H/C atomic ratios increases the energy content of the fuel source. This figure depicts that dry swine manure has $\mathrm{O} / \mathrm{C}$ and $\mathrm{H} / \mathrm{C}$ values of 0.5 and 1.6, respectively. These values placed dried manure in a location higher than that of cottonwood, as reported by Sadaka et al. [36]. These results revealed that raw manure solids could be co-fired with biomass. An interesting trend was observed by adding agricultural lime to coagulate swine manure solids. Increasing the agricultural lime concentration increased the $\mathrm{O} / \mathrm{C}$ and decreased the $\mathrm{H} / \mathrm{C}$ atomic ratios. A noticeable reduction in the heating values was observed, as depicted in the graph. In contrast, increasing hydrated lime or lime slurry concentrations increased the $\mathrm{H} / \mathrm{C}$ atomic ratios and it decreased the $\mathrm{O} / \mathrm{C}$ atomic ratio, which led to an overall reduction in the feedsrock heating value. The increase in oxygen concentration and the decrease in carbon concentration (Table 4) resulted in a noticeable rise in the $\mathrm{O} / \mathrm{C}$ ratio for amended manure samples. On the other hand, the hydrogen concentration reduction corresponding to the increase in coagulant addition increased the $\mathrm{H} / \mathrm{C}$ ratio. These two factors negatively affected the heating value of the produced feedstock. These results revealed that the lower the amendment addition, the higher the energy content of the coagulated swine manure samples. Nevertheless, these findings should be taken into consideration along with the outcome of the manure coagulation effectiveness.

It was essential to identify a unit function for the standardization of comparison. As a result, the unit function selected was $1 \mathrm{~kg}$ of the dried feedstock. It should be mentioned that this dry amount of feedstock started at different levels of the "as received" feedstock due to the variation in the initial moisture content levels. The total energy required to pyrolyze the wet feedstock could be obtained from the following equation:

$$
\mathrm{Q}_{\text {total }}=\mathrm{Q}_{\text {heating1 }}+\mathrm{Q}_{\text {drying }}+\mathrm{Q}_{\text {heating2 }}+\mathrm{Q}_{\text {pyrolysis }}
$$

where

$\mathrm{Q}_{\text {total }}$ is the total energy required for pyrolysis $\left(\mathrm{MJ} \cdot \mathrm{kg}^{-1}\right)$.

Qheating1: is the energy needed to heat the wet feedstock from $25^{\circ} \mathrm{C}$ to $100^{\circ} \mathrm{C}\left(\mathrm{MJ} \cdot \mathrm{kg}^{-1}\right)$.

$\mathrm{Q}_{\text {drying: }}$ is the energy required to dry the feedstock $\left(\mathrm{MJ}^{\circ} \cdot \mathrm{kg}^{-1}\right)$.

Qheating2: is the energy needed to heat the dried feedstock from $100^{\circ} \mathrm{C}$ to $550^{\circ} \mathrm{C}\left(\mathrm{MJ}^{-\mathrm{kg}^{-1}}\right)$.

$\mathrm{Q}_{\text {pyrolysis: }}$ is the energy required to pyrolyze the dried feedstock $\left(\mathrm{MJ} \cdot \mathrm{kg}^{-1}\right)$.

The energy needed to heat the feedstock $\left(\mathrm{Q}_{\text {heating1 }}\right)$ was determined by adding the required energy to heat its two components, i.e., manure and coagulant solids and moisture. Each constituent of the energy was determined by multiplying its mass, specific heat, and the difference in the temperature between $100^{\circ} \mathrm{C}$ and $25^{\circ} \mathrm{C}$. Specific heat capacity was assumed to be between $2.1-2.5 \mathrm{~kJ} \cdot \mathrm{kg}^{-1} \cdot{ }^{\circ} \mathrm{C}^{-1}$ for general organic materials [37]. The energy required to dry the feedstock was calculated by multiplying the water content and the latent heat of vaporization of water, $2090 \mathrm{~kJ} \cdot \mathrm{kg}^{-1}$ [38]. The energy required to heat the dried feedstock $\left(\mathrm{Q}_{\text {heating2 }}\right)$ was calculated in a similar manner to $Q_{\text {drying1 }}$ with the exception that no water exists as well as the temperature rise between $550^{\circ} \mathrm{C}-100^{\circ} \mathrm{C}$. The energy required to pyrolyze the dried feedstock, $Q_{\text {pyrolysis, }}$ was estimated to be $300.00 \mathrm{~kJ} \mathrm{~kg}^{-1}$ according to the literature [39].

The total energy required to pyrolyze raw manure reached $6.37 \mathrm{MJ} \cdot \mathrm{kg}^{-1}$, as shown in Figure 6. Increasing the 


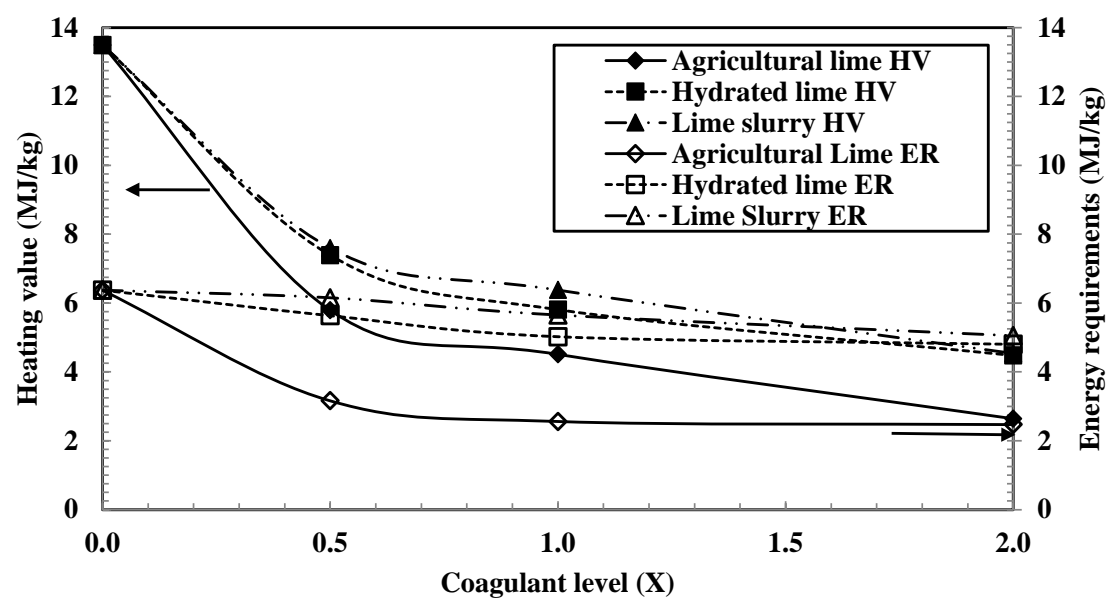

Figure 6. A comparison between the heating value (HV) and the energy required (ER) for pyrolysis for samples amendment with agricultural lime, hydrated lime, and lime slurry.

coagulant concentration decreased the energy needed for pyrolysis. The maximum energy required for pyrolysis of $6.15 \mathrm{MJ} / \mathrm{kg}$ was achieved with manure sample coagulated by lime slurry of $0.5 \mathrm{X}$, whereas the lowest energy needed for pyrolysis of $2.47 \mathrm{MJ} \cdot \mathrm{kg}^{-1}$ was achieved with manure sample coagulated by agricultural lime of $2.0 \mathrm{X}$. The reduction of the energy required for pyrolysis can be attributed to the significant reduction of the energy required for drying. The net energy, as designated by the difference between the energy content of the feedstock and the energy needed for pyrolysis, could be also perceived from Figure 6. The net energy showed positive values for the three coagulant types and concentrations with the two exceptions of hydrated lime and lime slurry of 2.0X. This figure depicts that the higher concentrations of chemical coagulant decreased the heating value of the coagulated sample to the extent that the energy content would not be sufficient to pyrolyze the feedstock.

\subsection{Assessment of Coagulated Swine Manure Solids as a Soil Amendment}

As mentioned earlier, Table 3 revealed that adding coagulants to separate swine manure solids affected its $\mathrm{pH}$ values. Five cases out of the nine studied cases showed that the $\mathrm{pH}$ values were far from optimal levels for composting. Velis et al. [40] reported that the optimum $\mathrm{pH}$ value for the composting process was in the range of 5.0 to 9.0. Adding agricultural lime $(0.5 \mathrm{X}, 1.0 \mathrm{X}$, and $2.0 \mathrm{X})$ as well as adding lime slurry $(0.5 \mathrm{X})$ were the only acceptable cases for the composting process in terms of $\mathrm{pH}$ value. In addition to manure $\mathrm{pH}$ value and nutrient content described earlier, carbon to nitrogen ratio $(\mathrm{C} / \mathrm{N})$ is a crucial parameter governing the decision of composting the feedstock. $\mathrm{C} / \mathrm{N}$ ratio is an important value that helps to evaluate the suitability of the feedstock as a soil amendment. C/N ratio of raw manure reached 8.93, as shown in Table 7. Although, the carbon concentration for the fresh manure was higher than that of any other sample (Table 4), its nitrogen concentration also was the highest. Accordingly, lower $\mathrm{C} / \mathrm{N}$ ratios were obtained. $\mathrm{C} / \mathrm{N}$ ratio of all the tested samples ranged between 15.54 and 22.23, indicating that these feedstocks could potentially be composted. Carbon concentration requires enhancement by adding a carbon source feedstock to reach the optimum C/N ratio of 30, as reported by Zhu [41]. Increasing the coagulant concentration increased the $\mathrm{C} / \mathrm{N}$ ratio for the two coagulants, i.e., agricultural lime and hydrated lime. The maximum $\mathrm{C} / \mathrm{N}$ ratio of 22.23 was observed with agricultural lime of 2.0X. Increasing the concentration of lime slurry did not show a similar trend as was found with agricultural lime and hydrated lime. Increasing the concentration of lime slurry from $0.5 \mathrm{X}$ to $1.0 \mathrm{X}$ decreased the $\mathrm{C} / \mathrm{N}$ ratio from 18.02 to 16.90 . Further increase in the lime slurry concentration to $2.0 \mathrm{X}$ increased the $\mathrm{C} / \mathrm{N}$ ratio once again to 17.69. Jørgensen and Jensen [28] reported a narrowing range of $\mathrm{C} / \mathrm{N}$ ratios $(7-14)$ for chemically separate swine manure. It might be due to the characteristics of the chemicals themselves. Another reason they mentioned was that manure was anaerobically digested before solid separation.

An important step in the preparation process of composting the produced feedstock is to determine the amount of bulking material required to adjust the $\mathrm{C} / \mathrm{N}$ ratio to reach the optimum range, i.e., 30. Bulking agents have low moisture content and high $\mathrm{C}$ contents [42]. When added to manure before composting, they increase the $\mathrm{C} / \mathrm{N}$ ratio, decrease overall moisture content, and improve the structure and porosity of the composting mix- 
ture. The composting of manure with a bulking agent results in an accelerated and odor-free process. The bulking agent absorbs excess moisture. The $\mathrm{C} / \mathrm{N}$ ratio of a mixture of two feedstocks could be obtained as follows:

$$
\mathrm{C} / \mathrm{N}=\left(\frac{\mathrm{Q} 1 \times(100-\mathrm{M} 1) \times \mathrm{C} 1+\mathrm{Q} 2 \times(100-\mathrm{M} 2) * \mathrm{C} 2}{\mathrm{Q} 1 \times(100-\mathrm{M} 1) \times \mathrm{N} 1+\mathrm{Q} 2 \times(100-\mathrm{M} 2) * \mathrm{~N} 2}\right)
$$

where:

$\mathrm{C} / \mathrm{N}$ : is the carbon to nitrogen ratio.

Q1: is the manure weight, $\mathrm{kg}$.

Q2: is the bulking material weight, $\mathrm{kg}$.

M1: is the manure moisture content, \%.

$\mathrm{C} 1$ : is the manure carbon concentration, $\mathrm{g} \cdot \mathrm{kg}^{-1}$.

$\mathrm{N} 1$ : is the manure nitrogen concentration, $\mathrm{g} \cdot \mathrm{kg}^{-1}$.

M2: is the bulking agent moisture content, \%.

C2: is the bulking agent carbon concentration, $\mathrm{g} \cdot \mathrm{kg}^{-1}$.

$\mathrm{N} 2$ : is the bulking agent nitrogen concentration, $\mathrm{g} \cdot \mathrm{kg}^{-1}$.

As a result, by rearranging the previous equation, the amount of the bulking agent could be determined using the following equation.

$$
\mathrm{Q} 2=\mathrm{Q} 1 *=\left(\frac{(\mathrm{C} / \mathrm{N} \times(100-\mathrm{M} 1) \times \mathrm{N} 1-(100-\mathrm{M} 1) \times \mathrm{C} 1)}{((100-\mathrm{M} 1) \times \mathrm{C} 2+\mathrm{C} / \mathrm{N} \times(100-\mathrm{M} 2) \times \mathrm{N} 2)}\right)
$$

Corn stalks were selected as a candidate feedstock with the assumption that its initial moisture, carbon and nitrogen contents are $11.00 \%, 41.18 \%$, and $0.78 \%$, respectively [43]. Table 7 shows the required amount of corn stalks to bring the $\mathrm{C} / \mathrm{N}$ ratio to 30 based on $1000 \mathrm{~kg}$ of the feedstock. The results showed that raw manure requires 1.65 ton/ton of corn stalks to reach the same C/N level. Sadaka and Ahn [43] biodried (partially compost) solid separated swine manure. They reported that adding crop residues to the manure enhanced the process performance and added more profit to producers since no external heat was supplied to dry the feedstock. They also mentioned that the biodrying process is a valid method for reducing manure corn stover moisture content and producing a feedstock suitable for thermochemical gasification technology.

It was observable from Table 7 that increasing the agricultural lime, hydrated lime, and lime slurry concentrations from $0.5 \mathrm{X}$ to $2.0 \mathrm{X}$ reduced the required amounts of corn stalks by $65.1 \%$ (from 0.75 to 0.26 ton/ton), $46.6 \%$ (from 0.26 to 0.18 ton/ton), and $23.6 \%$ (from 0.33 to 0.25 ton/ton), respectively. As mentioned earlier, a significant decrease in the carbon concentration was observed with the increase in coagulant concentration. Once again, from crop residues composting perspective, adding less bulking agent would be more desirable as less biomass would be transported.

Table 7. Carbon to nitrogen ratio, bulking agent requirements, hydrogen to carbon atomic and oxygen to carbon atomic ra-

\begin{tabular}{|c|c|c|c|c|c|}
\hline Treatment & Level & $C / \mathbf{N}^{1}(-)$ & $\mathrm{CS}^{2}$ (ton) & $\mathrm{H} / \mathrm{C}^{1}(-)$ & $\mathbf{O} / \mathbf{C}^{1}(-)$ \\
\hline \multirow[t]{2}{*}{ Manure } & Raw & 8.93 & 1.65 & 1.60 & 0.51 \\
\hline & $0.5 \mathrm{X}$ & 15.54 & 0.75 & 1.18 & 0.88 \\
\hline \multirow{3}{*}{$\begin{array}{l}\text { Agricultural } \\
\text { Lime }\end{array}$} & $1.0 \mathrm{X}$ & 19.70 & 0.42 & 1.00 & 1.07 \\
\hline & $2.0 \mathrm{X}$ & 22.23 & 0.26 & 0.89 & 1.20 \\
\hline & $0.5 X$ & 18.15 & 0.34 & 1.46 & 0.76 \\
\hline \multirow[t]{3}{*}{$\begin{array}{c}\text { Hydrated } \\
\text { Lime }\end{array}$} & $1.0 \mathrm{X}$ & 19.02 & 0.23 & 2.01 & 1.09 \\
\hline & $2.0 \mathrm{X}$ & 19.39 & 0.18 & 2.32 & 1.32 \\
\hline & $0.5 X$ & 18.02 & 0.33 & 1.38 & 0.74 \\
\hline \multirow{2}{*}{$\begin{array}{l}\text { Lime } \\
\text { Slurry }\end{array}$} & $1.0 \mathrm{X}$ & 16.90 & 0.36 & 1.47 & 0.87 \\
\hline & $2.0 \mathrm{X}$ & 17.69 & 0.25 & 1.99 & 1.72 \\
\hline
\end{tabular}
tios.

\footnotetext{
${ }^{1}$ Atomic ratio (-); ${ }^{2}$ Corn stalks (ton).
} 


\section{Conclusions}

From the experimental work described in this article, several important conclusions can be drawn:

- Increasing the coagulant treatment level increased the total solids, ash content, and $\mathrm{pH}$ of manure samples, whereas it decreased their volatile solids and heating value.

- The heating value of raw manure was $13.49 \mathrm{MJ} \cdot \mathrm{kg}^{-1}$, whereas it was $2.64 \mathrm{MJ} \cdot \mathrm{kg}^{-1}$ for agricultural lime, 4.48 $\mathrm{MJ} \cdot \mathrm{kg}^{-1}$ for hydrated lime, and $4.54 \mathrm{MJ} \cdot \mathrm{kg}^{-1}$ for lime slurry at the coagulant $36.13 \mathrm{gm} \cdot \mathrm{liter}{ }^{-1}$ rate.

- Increasing the coagulant concentration decreased the acceptability of the solid separated swine manure as a biofuel source.

- Based on the net energy, the maximum acceptable coagulant concentrations that allow pyrolyzing the final product were 48.80 (2.0X), 18.06 (1.0X), and 18.06 (1.0X) gm/liter for agricultural lime, hydrated lime, and lime slurry, respectively.

- Considering only the $\mathrm{C} / \mathrm{N}$ ratio increasing the coagulant concentration tended to increase the acceptability of the solid separated swine manure as a composting source.

- Based on the $\mathrm{pH}$ values, the maximum acceptable coagulant concentrations that allow composting the final product were $48.80(2.0 \mathrm{X}), 0.00(0.0 \mathrm{X})$, and $9.03(0.5 \mathrm{X}) \mathrm{gm} / \mathrm{liter}$ for agricultural lime, hydrated lime, and lime slurry, respectively.

\section{Acknowledgements}

This manuscript is a part of the USDA-NIFA project No. 2010-04269 titled "Integrated Resource Management Tools to Mitigate the Carbon Footprint of Swine Production in the US". The authors would like to thank the funding agency for their continued support. The authors also acknowledge the support of the Rice Research and Extension Center (RREC) in Stuttgart, Arkansas.

\section{References}

[1] USDA (2015) Quarterly Hogs and Pigs. http://www.usda.gov/nass/PUBS/TODAYRPT/hgpg0915.pdf

[2] ASABE (American Society of Agricultural and Biological Engineers) (2005) Standard D384.2-Manure Production and Characteristics. (Standard). American Society of Agricultural and Biological Engineers, St. Joseph.

[3] Riaño, B. and García-González, M.C. (2014) On-Farm Treatment of Swine Manure Based on Solid-Liquid Separation and Biological Nitrification-Denitrification of the Liquid Fraction. Journal of Environmental Management, 132, 87-93. http://dx.doi.org/10.1016/j.jenvman.2013.10.014

[4] Choudhary, M., Bailey, L.D. and Grant, C. A. (1996) Review of the Use of Swine Manure in Crop Production: Effect on Yield and Composition and on Soil and Water Quality. Waste Management \& Research, 14, 581-595. http://dx.doi.org/10.1177/0734242X9601400606

[5] Gebrezgabher, S.A., Meuwissen, M.P. and Lansink, A.G.O. (2014) A Multiple Criteria Decision Making Approach to Manure Management Systems in the Netherlands. European Journal of Operational Research, 232, 643-653. http://dx.doi.org/10.1016/j.ejor.2013.08.006

[6] Aguirre-Villegas, H.A., Larson, R. and Reinemann, D.J. (2014) From Waste-To-Worth: Energy, Emissions, and Nutrient Implications of Manure Processing Pathways. Biofuels, Bioproducts and Biorefining, 8, 770-793. http://dx.doi.org/10.1016/j.ejor.2013.08.006

[7] Hodgkinson, R.A., Chambers, B.J., Withers, P.J.A. and Cross, R. (2002) Phosphorus Losses to Surface Waters Following Organic Manure Applications to a Drained Clay Soil. Agricultural Water Management, 57, 155-173. http://dx.doi.org/10.1016/S0378-3774(02)00057-4

[8] Novak, J.M., Watts, D.W., Hunt, P.G. and Stone, K.C. (2000) Phosphorus Movement through a Coastal Plain Soil after a Decade of Intensive Swine Manure Application. Journal of Environmental Quality, 29, 1310-1315. http://dx.doi.org/10.1016/S0378-3774(02)00057-4

[9] Miller, J.J., Chanasyk, D.S., Curtis, T.W. and Olson, B.M. (2011) Phosphorus and Nitrogen in Runoff after Phosphorus- or Nitrogen-Based Manure Applications. Journal of Environmental Quality, 40, 949-958. http://dx.doi.org/10.2134/jeq2010.0279

[10] Salvano, E., Flaten, D.N., Rousseau, A.N. and Quilbe, R. (2009) Are Current Phosphorus Risk Indicators Useful to Predict the Quality of Surface Waters in Southern Manitoba, Canada? Journal of Environmental Quality, 38, 20962105. http://dx.doi.org/10.2134/jeq2008.0159

[11] Ribaudo, M., Kaplan, J.D., Christensen, L.A., Gollehon, N., Johansson, R., Breneman, V., Aillery, M., Agapoff, J. and 
Peters, M. (2003) Manure Management for Water Quality Costs to Animal Feeding Operations of Applying Manure Nutrients to Land. USDA-ERS Agricultural Economic Report 824.

[12] Walker, P. and Kelley, T. (2003) Solids, Organic Load and Nutrient Concentration Reductions in Swine Waste Slurry Using a Polyacrylamide (PAM)-Aided Solids Flocculation Treatment. Bioresource Technology, 90, 151-158. http://dx.doi.org/10.1016/S0960-8524(03)00116-0

[13] Hjorth, M., Christensen, K.V., Christensen, M.L. and Sommer, S.G. (2009) Solid-Liquid Separation of Animal Slurry in Theory and Practice-A Review. Agronomy for Sustainable Development, 30, 153-180.

http://dx.doi.org/10.1051/agro/2009010

[14] Ford, M. and Fleming, R. (2002) Mechanical Solid-Liquid Separation of Livestock Manure-Literature Review. Prepared for Ontario Pork, Ridgetown College, University of Guelph.

http://mie.esab.upc.es/ms/informacio/residus_ramaders/Separator\%20manure.pdf

[15] Rodriguez, M.D.E., del Puerto, A.M.G., Montealegre, M.L.M., Adamsen, A.P.S., Gullov, P. and Sommer, S.G. (2005) Separation of Phosphorus from Pig Slurry Using Chemical Additives. Applied Engineering in Agriculture, 21, 739-742. http://dx.doi.org/10.13031/2013.18549

[16] Zhang, R.H. and Westerman, P.W. (1997) Solid-Liquid Separation of Animal Manure for Odor Control and Nutrient Management. Applied Engineering in Agriculture, 13, 657-664. http://dx.doi.org/10.13031/2013.21644

[17] Xiu, S., Zhang, Y. and Shahbazi, A. (2009) Swine Manure Solids Separation and Thermochemical Conversion to Heavy Oil. BioResources, 4, 458-470.

[18] Hjorth, M., Christensen, M.L. and Christensen, P.V. (2008) Flocculation, Coagulation, and Coagulation of Manure Affecting Three Separation Techniques. Bioresource Technology, 99, 8598-8604. http://dx.doi.org/10.1016/j.biortech.2008.04.009

[19] Powers, W.J. and Flatow, L.A. (2002) Flocculation of Swine Manure: Influence of Flocculant, Rate of Addition, and Diet. Applied Engineering in Agriculture, 18, 609-614. http://dx.doi.org/10.13031/2013.10156

[20] Christensen, M.L., Hjorth, M. and Keidling, K. (2009) Characterization of Pig Slurry with Reference to Flocculation and Separation. Water Research, 43, 773-783. http://dx.doi.org/10.1016/j.watres.2008.11.010

[21] National Lime Association (2007) Lime Terminology, Standards \& Properties. Fact Sheet. https://lime.org/documents/publications/free_downloads/fact-properties2007rev.pdf

[22] ASTM E871-82 (2006) Standard Test Method for Moisture Analysis of Particulate Wood Fuels. ASTM International, West Conshohocken.

[23] ASTM E872-82 (2006) Standard Test Method for Volatile Matter in the Analysis of Particulate Wood Fuels. ASTM International, West Conshohocken.

[24] ASTM D2974-8 (2007) Standard Test Methods for Moisture, Ash, and Organic Matter of Peat and Organic Soils. ASTM International, West Conshohocken.

[25] ASTM D5373-14 (2014) Standard Test Methods for Determination of Carbon, Hydrogen and Nitrogen in Analysis Samples of Coal and Carbon in Analysis Samples of Coal and Coke. ASTM International, West Conshohocken.

[26] ASTM D4239-14e1 (2014) Standard Test Method for Sulfur in the Analysis Sample of Coal and Coke Using HighTemperature Tube Furnace Combustion. ASTM International, West Conshohocken.

[27] ASTM D5865-12 (2012) Standard Test Method for Gross Calorific Value of Coal and Coke. ASTM International, West Conshohocken.

[28] Jørgensen, K. and Jensen, L.S. (2009) Chemical and Biochemical Variation in Animal Manure Solids Separated Using Different Commercial Separation Technologies. Bioresource Technology, 100, 3088-3096. http://dx.doi.org/10.1016/j.biortech.2009.01.065

[29] Wnetrzak, R., Kwapinski, W., Peters, K., Sommer, S.G., Jensen, L.S. and Leahy, J.J. (2013) The Influence of the Pig Manure Separation System on the Energy Production Potentials. Bioresource Technology, 136, 502-508. http://dx.doi.org/10.1016/j.biortech.2013.03.001

[30] Marchetti, R., Castelli, F., Orsi, A., Sghedoni, L. and Bochicchio, D. (2012) Biochar from Swine Manure Solids: Influence on Carbon Sequestration and Olsen Phosphorus and Mineral Nitrogen Dynamics in Soil with and without Digestate Incorporation. Italian Journal of Agronomy, 7, 26. http://dx.doi.org/10.4081/ija.2012.e26

[31] Vanotti, M.B., Rice, J.M., Ellison, A.Q., Hunt, P.G., Humenik, F.J. and Baird, C.L. (2005) Solid-Liquid Separation of Swine Manure with Polymer Treatment and Sand Filtration. Transactions of the ASAE, 48, 1567-1574. http://dx.doi.org/10.13031/2013.19190

[32] Tsai, W.T. and Liu, S.C. (2012) Thermochemical Characterization of Separated Swine Manure Utilized as an Available Energy Source and Its Preliminary Benefit Analysis in Taiwan. Energy Education Science and Technology Part A-Energy Science and Research, 30, 565-576. 
[33] Park, M.H., Kumar, S. and Ra, C. (2012) Solid Waste from Swine Wastewater as a Fuel Source for Heat Production. Asian-Australasian Journal of Animal Sciences, 25, 1627-1633. http://dx.doi.org/10.5713/ajas.2012.12302

[34] Zhang, L., Duan, F. and Huang, Y. (2015) Thermogravimetric Investigation on Characteristic of Biomass Combustion under the Effect of Organic Calcium Compounds. Bioresource Technology, 175, 174-181. http://dx.doi.org/10.1016/j.biortech.2014.10.077

[35] Van Krevelen, D.W. (1993) Coal: Typology, Physics, Chemistry, Constitution. 3rd Edition, Elsevier, Amsterdam.

[36] Sadaka, S., Liechty, H., Pelkki, M. and Blazier, M. (2015) Pyrolysis and Combustion Kinetics of Raw and Carbonized Cottonwood and Switchgrass Agroforests. BioResources, 10, 4498-4518. http://dx.doi.org/10.15376/biores.10.3.4498-4518

[37] Perry, H.R. and Chilton, C.H. (1984) CH Chemical Engineers’ Handbook. Volume 6, McGraw-Hill, New York, 11-46.

[38] Day, D.L., Funk, T.L., Hatfield, J.L. and Stewart, B.A. (1998) Processing Manure: Physical, Chemical and Biological Treatment. In: Animal Waste Utilization: Effective Use of Manure as a Soil Resource, Ann Arbor Press, Chelsea, MI, 243-282.

[39] Rath, J., Wolfinger, M.G., Steiner, G., Krammer, G., Barontini, F. and Cozzani, V. (2003) Heat of Wood Pyrolysis. Fuel, 82, 81-91. http://dx.doi.org/10.1016/S0016-2361(02)00138-2

[40] Velis, C.A., Longhurst, P.J., Drew, G.H., Smith, R. and Pollard, S.J. (2009) Biodrying for Mechanical-Biological Treatment of Wastes: A Review of Process Science and Engineering. Bioresource Technology, 100, 2747-2761. http://dx.doi.org/10.1016/j.biortech.2008.12.026

[41] Zhu, N. (2007) Effect of Low Initial C/N Ratio on Aerobic Composting of Swine Manure with Rice Straw. Bioresource Technology, 98, 9-13. http://dx.doi.org/10.1016/j.biortech.2005.12.003

[42] Bernal, M.P., Alburquerque, J.A. and Moral, R. (2009) Composting of Animal Manures and Chemical Criteria for Compost Maturity Assessment-A Review. Bioresource Technology, 100, 5444-5453. http://dx.doi.org/10.1016/j.biortech.2008.11.027

[43] Sadaka, S. and Ahn, H. (2012) Evaluation of a Biodrying Process for Beef, Swine, and Poultry Manures Mixed Separately with Corn Stover. Applied Engineering in Agriculture, 28, 457-463. http://dx.doi.org/10.13031/2013.41482 